Neurology

Edited by Geraint Fuller MD FRCP,

Consultant Neurologist, Gloucester Royal Hospital

\section{Acute and subacute}

\section{weakness}

Marguerite Hill MRCP DPhil, Consultant

Senior Lecturer in Neurology, Institute of Clinical Neurosciences, Frenchay Hospital, Bristol

Clin Med 2004;4:105-7

To be faced with a patient getting weaker day by day or hour by hour is a daunting prospect. Accurate clinical assessment of the patient is crucial (Table 1, Fig 1) as the results of diagnostic tests may be delayed for several days or be misleading in the early stages of the disease. This article will review only the assessment, investigation and management of patients with spinal cord or neuromuscular disease; weakness caused by lesions above the foramen magnum will be discussed in another paper in this section by Neil Scolding.

\section{Spinal cord disease}

Diagnosing spinal cord pathology is relatively easy if the patient presents with a spastic paraparesis. However, acute spinal injury can initially present with flaccid weakness and areflexia, making differentiation from a polyneuropathy difficult. The following features suggest a spinal cord lesion:

- Lhermitte's phenomenon (electric shock-like feelings down the arms and legs on neck flexion)

- a sensory level

- a dissociated sensory loss (ie proprioceptive loss ipsilateral to and pain and temperature loss contralateral to the lesion Brown-Séquard syndrome)

- root pain at the upper level

- sphincter involvement at presentation

- a lower motor neurone 'level' (eg weak elbow flexion and an absent biceps reflex).

Sensory levels may, however, be deceptive, as the causative lesion may be much higher than the level would suggest. The physiological basis of this is not clear. If there is any suspicion that the patient may have cord disease, urgent magnetic resonance is mandatory, imaging the spine from any motor or sensory level up to the top of the cervical spine. It is important to be aware that high cervical cord disease can result in respiratory failure from involvement of either the phrenic nerve or the respiratory centres in the upper cervical cord; such patients therefore require careful respiratory monitoring.

\section{Peripheral neuropathies}

\section{Guillain-Barré syndrome}

The typical patient with Guillain-Barré syndrome (GBS) presents with rapidly progressive weakness that often starts proximally and may include the face, absent reflexes and distal sensory disturbance. Many patients complain of severe back pain that is thought to be secondary to root inflammation. It may be possible to elicit a history of an upper respiratory tract or gastrointestinal illness a week or two before the weakness. Sensory symptoms and signs are not required for the diagnosis as a pure motor variant is well recognised. Some patients may initially retain their reflexes but they should always disappear in established disease. The development of sphincter symptoms while the weakness is progressing raises the possibility of cord disease and should be appropriately investigated.

The initial diagnosis of GBS is often made on clinical grounds. A lumbar puncture should be performed if there are no contraindications. An elevated protein level adds support to the diagnosis, but may be normal during the first few days of symptoms. A cerebrospinal fluid leukocytosis $\left(>10 / \mathrm{mm}^{3}\right)$ should prompt the search for an alternative diagnosis.

Acute management involves careful monitoring of cardiac (rhythm and blood pressure) and respiratory function. A rising respiratory rate and falling forced vital capacity (FVC) $(20 \mathrm{ml} / \mathrm{kg})$ should prompt an anaesthetic review. Peak flow measurements and pulse oximetry are not adequate. Deep vein thrombosis prophylaxis is advisable. The rate of recovery is increased by treatment with intravenous immunoglobulin (IVIg) $0.4 \mathrm{~g} / \mathrm{kg} /$ day for five days or plasma exchange, ${ }^{1,2}$ but the effect on overall outcome has been disappointing. There is no evidence that steroid treatment is beneficial. ${ }^{3}$

\section{Vasculitic neuropathy}

The classic presentation of vasculitis affecting the peripheral nervous system is sequential dysfunction of individual peripheral nerves (mononeuritis multiplex). However, where multiple nerves are being picked off with great rapidity the presentation can be a rapidly progressive, often extremely painful, distal neuropathy. Diagnostic clues include involvement of other organs such as vasculitic skin lesions, renal disease, an inflammatory arthropathy, raised inflammatory markers or an eosinophilia. These conditions need to be treated quickly and aggressively with high-dose parenteral steroids and cyclophosphamide to avoid progressive, irreversible organ damage. It is therefore important to try to confirm the diagnosis as quickly as possible, preferably with demonstration of vasculitis on biopsy of affected tissue. 
Table 1. Summary of the typical presentation of different causes of rapidly progressive weakness according to reflex changes. (The list of differential diagnoses is not exhaustive but should act as a guide when assessing such patients.)

\begin{tabular}{|c|c|c|c|c|c|c|c|}
\hline \multirow{2}{*}{$\begin{array}{l}\text { Reflex changes } \\
\text { Associated symptoms } \\
\text { and signs }\end{array}$} & \multirow{2}{*}{$\begin{array}{l}\text { Brisk reflexes } \\
\text { - Bilateral upgoing } \\
\text { plantars } \\
\text { - Sensory signs } \\
\text { (eg level) } \\
\text { - Urinary retention }\end{array}$} & \multicolumn{2}{|c|}{ Normal reflexes } & \multicolumn{2}{|c|}{ Patchy reflex changes } & \multicolumn{2}{|c|}{ Absent reflexes } \\
\hline & & $\begin{array}{l}\text { - Proximal } \\
\text { weakness } \\
\text { - No sensory } \\
\text { changes } \\
\text { - Rash* } \\
\text { - Myalgia* }\end{array}$ & $\begin{array}{l}\text { - Fatiguable ptosis } \\
\text { - Diplopia } \\
\text { - Dysarthria } \\
\text { - Dysphagia } \\
\text { - Proximal muscle } \\
\text { weakness }\end{array}$ & $\begin{array}{l}\text { - Mononeuritis } \\
\text { multiplex } \\
\text { - Pain } \\
\text { - Erosive } \\
\text { arthopathy* } \\
\text { - Vasculitic skin } \\
\text { lesions* } \\
\text { - Renal failure* }\end{array}$ & $\begin{array}{l}\text { - Facial weakness* } \\
\text { - Distal sensory loss* } \\
\text { - Back pain* }\end{array}$ & $\begin{array}{l}\text { - Sensory signs } \\
\text { (eg level) }\end{array}$ & $\begin{array}{l}\text { - Ptosis } \\
\text { - Diplopia } \\
\text { - Blurred vision* } \\
\text { - Autonomic } \\
\text { disturbances }\end{array}$ \\
\hline Differential diagnosis & $\begin{array}{l}\text { - Spinal cord } \\
\text { pathology }\end{array}$ & $\begin{array}{l}\text { - Inflammatory } \\
\text { myositis } \\
\text { - Drug-induced } \\
\text { myositis } \\
\text { - Metabolic } \\
\text { myopathy } \\
\text { - Viral myositis }\end{array}$ & - Myasthenia gravis & - Vasculitis & $\begin{array}{l}\text { - Guillain-Barré } \\
\text { syndrome }\end{array}$ & $\begin{array}{l}\text { - Spinal cord } \\
\text { pathology }\end{array}$ & $\begin{array}{l}\text { - Botulism } \\
\text { - Lambert-Eaton } \\
\text { myasthenic } \\
\text { syndrome } \\
\text { - Guillain-Barré } \\
\text { syndrome }\end{array}$ \\
\hline Investigations & $\begin{array}{l}\text { - } \mathrm{MRI} \\
\text { - Lumbar puncture }\end{array}$ & $\begin{array}{l}\text { - Creatine kinase } \\
\text { - Serum } \\
\text { biochemistry } \\
\text { - Muscle biopsy }\end{array}$ & $\begin{array}{l}\text { - Serum anti- } \\
\text { acetylcholine } \\
\text { receptor antibody } \\
\text { titre } \\
\text { - Neurophysiology } \\
\text { - Tensilon test }\end{array}$ & $\begin{array}{l}\text { - Serum } \\
\text { inflammatory } \\
\text { markers } \\
\text { - Auto antibody } \\
\text { titres } \\
\text { - Nerve/skin/renal } \\
\text { biopsy }\end{array}$ & $\begin{array}{l}\text { - Lumbar puncture } \\
\text { - Nerve conduction } \\
\text { studies }\end{array}$ & $\begin{array}{l}\text { - } \mathrm{MRI} \\
\text { - Lumbar puncture }\end{array}$ & $\begin{array}{l}\text { - Nerve conduction } \\
\text { studies } \\
\text { - Anti-voltage } \\
\text { gated calcium } \\
\text { channel } \\
\text { antibodies }\end{array}$ \\
\hline
\end{tabular}

* variable.

$\mathrm{MRI}=$ magnetic resonance imaging .

\section{Neuromuscular junction disorders}

\section{Myasthenia gravis}

Myasthenia gravis is by far the most common neuromuscular junction disorder; it is most likely to present acutely as a 'myasthenic crisis' - rapidly progressive weakness particularly affecting the bulbar and respiratory muscles. A cholinergic crisis from excessive doses of cholinesterase inhibitors is rare. Lambert-Eaton myasthenic syndrome (LEMS) can present with respiratory failure, but this is an unusual manifestation of a rare condition. LEMS generally presents with subacute proximal weakness (particularly of the legs), absent reflexes and autonomic dysfunction. Bulbar and respiratory function should be carefully monitored in an acutely deteriorating myasthenic. If the patient coughs, chokes or has a bubbly voice after swallowing a teaspoon of water, a nasogastric tube should be inserted. Rapidly deteriorating respiratory function, as assessed by increasing respiratory rate and falling FVC, is a sign of impending intubation. Such patients will not be controlled with high-dose cholinesterase inhibitors. Neostigmine should be used with extreme caution because of the high incidence of cholinergic side effects, and should never be administered intravenously.

Short-term remission may be achieved by plasma exchange or IVIg, but steroids are the mainstay of treatment, aiming for a dose of $1 \mathrm{mg} / \mathrm{kg} /$ day. Patients already requiring respiratory support can be started on this dose, but steroids should be introduced cautiously in those with generalised disease not requiring intensive care because they can precipitate an acute deterioration in symptoms.

Myasthenia is often misdiagnosed, particularly in the elderly. Diagnostic clues include both ptosis and weakness of eye closure, clear fatiguability and variable signs when examined at different times of day. It would be unusual to have limb weakness without bulbar and/or ocular symptoms. Distal weakness is recognised but rare. Extraocular muscle weakness in myasthenia gravis can look like nystagmus, giving the mistaken impression that the lesion is intracranial. There is often a delay before the diag-

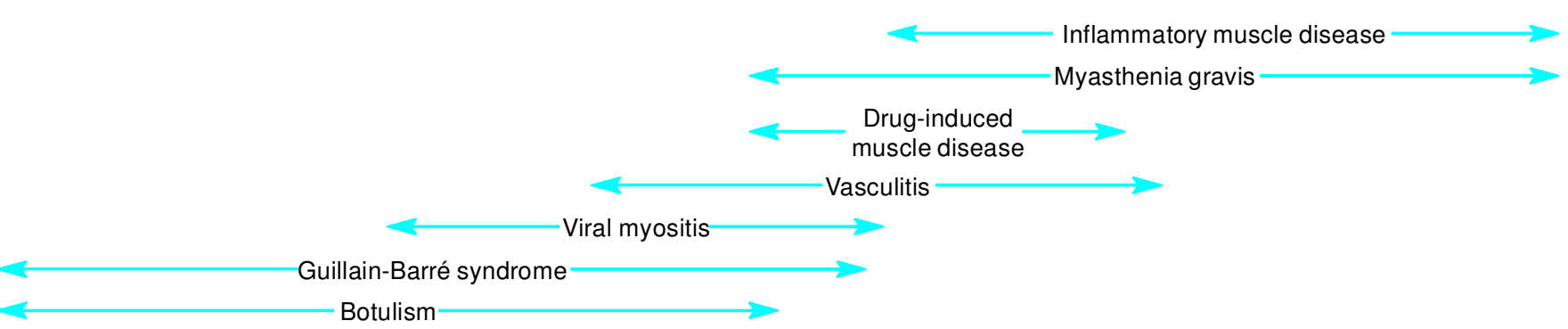

Fig 1. Time line giving approximate rate of onset of different conditions that can present with generalised weakness. 
nosis can be confirmed by a positive titre of anti-acetylcholine receptor antibodies or detailed neurophysiological studies, so there is still a place for the Tensilon test (edrophonium challenge test) in symptomatic patients. However, a mortality is associated with this test and it is open to misinterpretation, so should be performed only by an experienced clinician.

\section{Botulism}

Botulism should form part of the differential diagnosis of any individual presenting with rapidly progressing weakness, particularly if there is a history of IV drug abuse. Diagnostic clues are presence of autonomic symptoms and signs early in the disease, such as sluggish pupil reactions and xerostomia, and weakness spreading from the 'top down'. Neurophysiological examination greatly assists in making the diagnosis. By the time the diagnosis is appreciated, the window of opportunity for administration of antiserum is usually long gone so treatment is supportive. If wound botulism is suspected, a careful search should be made for the focus of infection and the wound debrided.

\section{Muscle disease}

Acquired inflammatory muscle disease can present with rapid proximal weakness, dysphagia and respiratory failure, though in most cases the onset is more insidious. Pain is a relatively uncommon feature, and the diagnostic pointers are marked proximal weakness with preservation of distal strength and reflexes (at least in the early stages) and sparing of the ocular muscles. Creatine kinase (CK) levels are often grossly elevated. The muscle biopsy may be diagnostic, though it may be normal even in classical cases because of the patchy nature of the disease.

\section{Viral myositis}

Viral myositis can present with rapidly progressive weakness and may be confused with GBS. Muscles are often tender and the CK elevated. The condition is generally benign and self-limiting, though Coxsackie infection can cause a

\section{Key Points}

Respiratory failure is a common complication of acute neuromuscular disease and
high cervical cord lesions and should be monitored by measuring forced vital
capacity and respiratory rate

Urgent imaging is mandatory if there is any clinical suspicion of spinal cord disease

Treatment of Guillain-Barré syndrome with plasma exchange or intravenous immunoglobulin (IVIg) speeds up the rate of recovery

Treatment of patients in a myasthenic crisis with plasma exchange or IVIg often results in significant short-term improvement

A drug side effect or metabolic disturbance should be considered in a patient presenting acutely with proximal weakness, myalgia and high creatine kinase

KEY WORDS: Guillain-Barré syndrome, myasthenia gravis, spinal cord disease

cardiomyopathy and respiratory failure. Hypokalaemia, hypomagnesaemia and hypophosphataemia can cause muscle weakness, necrosis and even marked rhabdomyolysis. Conditions that predispose towards such metabolic disturbances include endocrinological disturbances such as a diabetic ketoacidosis, alcoholism and excessive ingestion of potassiumlosing compounds such as laxatives, diuretics and liquorice.

\section{Drug-induced myopathy}

In a patient presenting with progressive proximal weakness and myalgia, consideration should always be given to drug-induced myopathy - particularly relevant with the growing use of statins, although many medications can cause muscle damage. The combination of a statin with a fibrate is particularly risky. A clinically significant statin myopathy is generally accompanied by a significant elevation in CK levels. If unrecognised, it can progress to renal failure, and deaths have been reported. ${ }^{4}$ There will usually be recovery of the muscle if the offending drug is stopped.

\section{Summary}

The key step when evaluating a patient with progressive weakness is to establish if the pathology is above or below the anterior horn cell. Lesions above require urgent imaging; more distal pathologies often have an inflammatory basis and may respond to immunomodulatory drugs. It is vital to remember that, whatever the cause, progressive generalised weakness will often affect respiratory and bulbar function. Such patients therefore require close monitoring with respiratory support if indicated.

\section{Acknowledgements}

I am grateful to Ian Ormerod, Andrew Levy and Geraint Fuller for critical reading of the manuscript.

\section{References}

1 Raphaël JC, Chevret S, Hughes RAC, Annane D. Plasma exchange for GuillainBarré syndrome (Cochrane Review). In: The Cochrane Library, Issue 2, 2002. Oxford: Update Software.

2 Hughes RA, Raphaël JC, Swan AV, van Doorn PA. Intravenous immunoglobulin for Guillain-Barré syndrome (Cochrane Review). In: The Cochrane Library, Issue 3, 2003. Oxford: Update Software.

3 Hughes RA, van der Meché FG. Corticosteroids for Guillain-Barré syndrome (Cochrane Review). In: The Cochrane Library, Issue 3, 2003. Oxford: Update Software.

4 Sieb JP, Gillessen T. Iatrogenic and toxic myopathies. Review. Muscle Nerve 2003; 27:142-56. 